\title{
The potential for locating hydrocarbon traps in the Rotliegend formation, based on the results of experimental seismic surveys
}

\author{
Tomasz Maćkowski ${ }^{1}$, Krzysztof Kwolek² ${ }^{2}$ Wojciech Górecki ${ }^{1}$ \\ ${ }^{1}$ AGH University of Science and Technology, Faculty of Geology, Geophysics and Environmental Protection, \\ Department of Fossil Fuels; al. A. Mickiewicza 30,30-059 Krakow, Poland; e-mail:wgorecki@agh.edu.pl, mackowsk@agh.edu.pl \\ ${ }^{2}$ Polish Oil and Gas Company, ul. M. Kasprzaka 25, 01-224 Warsaw, Poland; e-mail: krzysztof.kwolek@pgnig.pl
}

(C) 2017 Authors. This is an open access publication, which can be used, distributed and reproduced in any medium according to the Creative Commons CC-BY 4.0 License requiring that the original work has been properly cited.

Received: 4 October 2017; accepted: 5 January 2018

\begin{abstract}
Within the framework of the Operational Programme Innovative Economy 2007-2013, studies were carried out for improving the effectiveness of using seismic surveys in the prospecting and exploration of gas fields in the Rotliegend formation.

The completed experimental seismic surveys provided new, very interesting data on the geological structure of the deeper part of the Rotliegend basin $(>4000 \mathrm{~m}$ ), which is practically very important for prospecting for new gas fields. The interesting results were obtained along virtually the entire cross-section, particularly in two segments: the southern segment - in front of and within the Człopa-Szamotuly tectonic zone (the Szczecin-Gorzów segment) and the northern segment - in the area of the Zabartowo-1 and Zabartowo-2 wells (the Pomeranian segment). In the northern segment, for the first time in the history of studies of the Lower Permian Basin, it was possible to record reflections from the horizon of the aeolian sandstones occurring within the playa silty-clayey deposits (543 $\mathrm{m}$ below the top of the Rotliegend formation), which represents a significant achievement from the point of view of prospecting for hydrocarbon resources. This horizon, characterized by favourable reservoir properties, pinches out northward. It is a very important piece of information because systems of lithologic traps may be related to such pinchouts. In the central part of the Obrzycko-Zabartowo profile, in the Chodzież area, a vast structural elevation occurs, approximately $10-12 \mathrm{~km}$ wide and with the amplitude of 250-300 m, which may be a potential large structural or structural and lithologic trap.

These newly discovered zones of occurrence of gas traps in the seismic profiles made by the AGH University of Science and Technology within the framework of the research project, will be implemented in a detailed seismic exploration during the exploratory work of Polish Oil and Gas Company (PGNiG SA).
\end{abstract}

Keywords: Rotliegend, seismic survey, lithologic traps, Chodzież trap

\section{INTRODUCTION}

The Rotliegend basin is very attractive for prospecting for gas traps. Geological and thermodynamic conditions were favourable there for the generation and accumulation of substantial amounts of gaseous hydrocarbons, genetically related to the Carboniferous source rocks (Burzewski et al., 2009).
The European Rotliegend basin extends from Central and Western Poland, to Northern Germany and the Netherlands, and to the east coast of England (Fig. 1). In this region, significant gas fields have been discovered, with total recoverable reserves of approximately $5.6 \times 10^{12} \mathrm{~m}^{3}$.

The largest gas field, Gröningen, was discovered in the Netherlands and its recoverable reserves amount to $2.77 \times 10^{12} \mathrm{~m}^{3}$. The exploration 
was successful also in the British zone, where gas reserves of $1.2 \times 10^{12} \mathrm{~m}^{3}$ were documented. The Rotliegend gas accumulations occur in sandstones of the aeolian and fluvial (wadi) facies, and in the British sector - in lacustrine sandbodies. A number of gas fields of Germany and the Netherlands, including largely the Gröningen field, are reservoired in fluvial facies deposits. The depth range of the gas field occurrences is $3000-4000 \mathrm{~m}$ in the northern part and 2000-3000 $\mathrm{m}$ in the southern part. In the Netherlands, the gas fields occur at depths from $2000 \mathrm{~m}$ to $4000 \mathrm{~m}$. The German gas fields, including the largest Salzwedel-Peckensen field, are located at depths of 3200-3600 m. According to Gautier (2003), a number of German fields are related to depths from $4000 \mathrm{~m}$ to $6000 \mathrm{~m}$. Interestingly, reservoir properties of the Rotliegend aeolian sandstones in the 5000-6000 $\mathrm{m}$ depth interval are better than those of sandstones resting in the upper part of this formation. Such a situation can be observed in the Solingen field, where sandstones reveal porosities to $15 \%$ and permeability from 1 to $10 \mathrm{mD}$. The probable increase of porosity with depth is related to coarser grain fractions in deeper sandstones, which to a greater extent enabled the preservation of initial porosity and permeability in comparison with finegrained sandstones.

Similar reservoir models, with good reservoir properties at great depths (4500-6500 m) and intraformational sealing in the profile, can be expected in the Polish Rotliegend basin, including its central part (Papiernik et al. 2010). It significantly improves the exploration opportunities and prospects for discovering gas fields with resources from more than ten up to several hundred billion cubic meter of gas.

Gas reservoirs in the Rotliegend deposits are generally sealed by evaporite rocks. A number of the gas fields in the British sector, connected with lacustrine deposits, are sealed by claystones of the Rotliegend. In the Morkham gas field and Windermere gas field (Bailey \& Lloyd 2001), natural gas accumulates in aeolian sandstones, $20-40$ m thick, resting upon Westphalian source rocks and sealed by silty deposits of the playa and sebha facies.

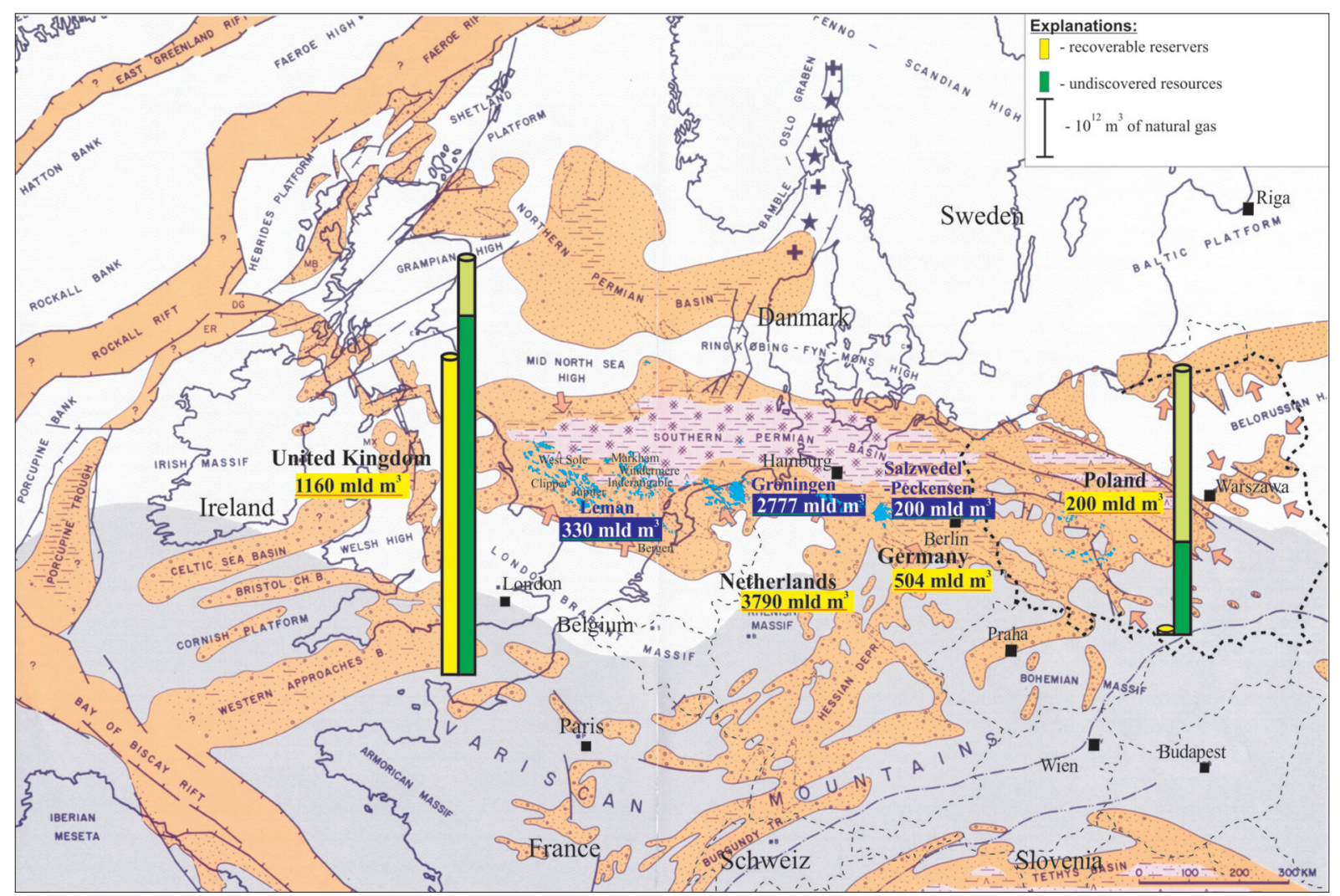

Fig. 1. Natural gas fields in the Rotliegend deposits against the background of the Early Permian paleogeography (Ziegler 1990, modified by Górecki 2005) 
The Rotliegend gas fields have been charged by gas generated in source rocks of the Carboniferous that underlies practically the entire Rotliegend basin. Conford (1998) evidenced by the fact that the gas resources in the Sale Pit basin equal to $693 \times 10^{9} \mathrm{~m}^{3}$ could have been generated by a coal bed less than $0.5 \mathrm{~m}$ thick. The Southern Permian Basin, with the total thickness of coal beds in the Carboniferous sequences ranging from $75 \mathrm{~m}$ to $100 \mathrm{~m}$ and with much thicker coal shales, could have provided a gas amount sufficient for filling all of the existing hydrocarbon traps (Glennie 1990).

The Rotliegend reservoir rocks represent a priority exploration target in practically the entire Polish zone of its occurrence at depths from $3500 \mathrm{~m}$ to $6000-6500 \mathrm{~m}$. Gas fields can be related to structural and stratigraphic traps, with gas resources ranging from several, to more than ten, up to several hundred billion $\mathrm{m}^{3}$, were never expected in the past. It should be stressed that the Rotliegend deposits in Poland have been recognized down to 3000-3500 $\mathrm{m}$ in the Fore-Sudetic Monocline and Western Pomerania. The entire central part of the basin and the eastern limb of the basin were only penetrated by individual wells and, as a rule, explored with seismic surveys carried out dozens of years ago. Also, the discovered gas fields are enclosed by the 3000-4000 $\mathrm{m}$ isohypses and to achieve exploration success, it is necessary to shoot experimental seismic lines including the most prospective zones of the Rotliegend formation (Górecki 2008). The quality of the new seismic profiles has enabled the much better recognition of the subsurface geological structure and location of traps with potential abundant resources. Deep wells (3500-6000 m) afford a route to the new gas discoveries.

\section{IMPROVEMENT \\ OF THE EFFECTIVENESS OF SEISMIC SURVEYS}

To achieve the improvement of the effectiveness of seismic methods, multivariant tests of parameters of seismic data measurements were made for the AGH1 profile at the Golce-1 well. Successively, three regional lines were shot: Obrzycko-
-Zabartowo (AGH2), Golęczewo-Szubin (AGH3) and Rokietnica-Objezierze (AGH4) (Fig. 2). Their methodological task was to verify the selected optimal measurement parameters obtained based on the experimental "Golce-AGH1" profile. Also, the key parameter - the length of the maximum offset (the distance from a shotpoint to a receiver) - was tested (Górecki \& Maćkowski 2015).

Seismic sections elaborated within the framework of the "Golce-AGH1" seismic experiment for most variants of data acquisition reveal a significant improvement in the imaging of the geological structure beneath the base of the Zechstein rocks. For the first time in the Polish segment of the Rotliegend basin, it was possible to obtain seismic reflections related to the sandstone layer underlying the thick clayey-silty deposits of the playa and it was demonstrated that it is possible to trace the basement of clastic deposits of the Upper Rotliegend. It results from the fact that those multivariant seismic measurements that increase the amount of sweeps over 16 sweeps per one shotpoint do not result in the increase of the signal-to-noise ratio or an improvement of the correlativeness of seismic records. Also, no improvement of the section quality through extension of the sweep and the increase of the amount of vibrators per one shotpoint (from 4 to 6 or 8) can be observed. A larger number of vibrators gives higher signal energy but also increases the background and some unfavourable effects of the grouping of sources appear, which is connected with the reduction of the horizontal resolution of seismic recording. Among the tested sweep types, two are optimal from the point of view of the imaging of the geological medium beneath the basement of the Zechstein rocks: a linear sweep with the $6-80 \mathrm{~Hz}$ frequency band and a dedicated sweep. A decisive improvement of the parameters of the seismic section can be observed in the case of the increased fold and spatial wavefield sampling. It was evidenced that the maximum fold for positive results should exceed 150 in zones without the occurrence of salt diapirs and high pillows. However, in case of the seismics aimed at the reconstruction of actual amplitude relationships, a fold to the order of 650 is required. In areas with developed salt tectonics, the length of the maximum offset is of decisive importance. It was established that for the deeper 
part of the basin, the optimal maximum offset ranges from 8 to $10 \mathrm{~km}$. Furthermore, the recording of the wavefield in a dense pattern of reception points, e.g. every $10 \mathrm{~m}$, is required. Owing to the applied methodology of seismic data acquisition and processing, for the first time it was possible to image the reflection related to the base of the Szamotuły tectonic and salt structure and Wapno salt dome in the seismic record, as well as beneath high and steep salt pillows, which proves the ability to seismically detect hydrocarbon traps in the basement of salt structures in the deep part of the Rotliegend basin.

The main objective of the project within the range of prospecting for new gas fields was to examine the possibilities for the seismic mapping of reservoir traps within the Rotliegend deposits in the deeper part of the Rotliegend basin. On the basis of comprehensively processed seismic materials and their structural and tectonic interpretation, as well as analyses in the area of seismic reservoir characterization (inversion, attribute analysis) in combination with geological premises derived from sparse wells in this zone or nearby, together with a theoretical consideration of the architecture of the Rotliegend basin, occurrence of the following types of reservoir traps was established: structural, lithologic and combination traps. Their basic parameters were given.

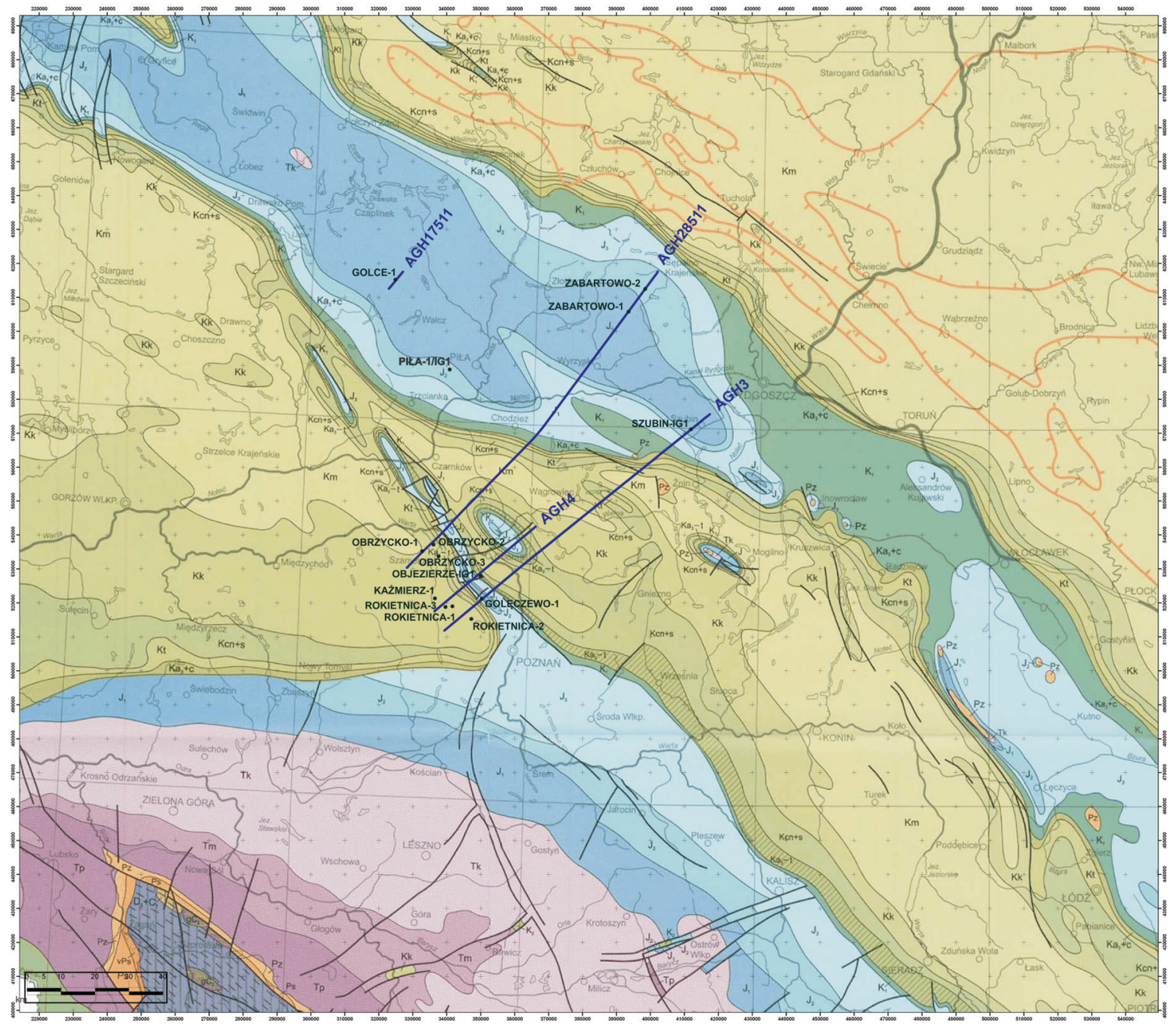

Fig. 2. Location of AGH seismic profiles on the background of Cenozoic subcrop map (Dadlez et al. 2000) 


\section{STRUCTURAL TRAPS}

The Obrzycko-Zabartowo (AGH2) research profile indicated the presence of a vast structural elevation in the area of Chodzież (on the Pomeranian Swell), approximately $10-12 \mathrm{~km}$ wide and with the amplitude of $250-300 \mathrm{~m}$. It is difficult to prejudge its spatial setting - it may be a closed structure as well as a structural nose (Fig. 3). Studies of the regional seismic profile (AGH28511) and geological analysis combined with the analysis of archival seismic 2D profiles in the area of the Chodzież Elevation, perpendicular to the analysed profile (that is directed NW-SE), demonstrated a steady rising of the top of the basement of the Zechstein rocks toward NW. From the facies distribution in the Rotliegend basin it is known that in the Chodzież area (the central part of the basin) clayey-silty deposits of the playa type occur, with interlayers of aeolian sandstones within the lower part of the Upper Rotliegend, which pinch out toward NW. Therefore, the Chodzież Elevation may actually represent a combination structural and lithologic trap. However, at the current stage of recognition, this object has been presented as a large-size structural trap.

A tectonically sealed structural trap was detected in the seismic record of the SW fragment of the AGH3 Golęczewo-Szubin profile on the Rokietnica Elevation (Fig. 4). The trap is actually an eastward extension of the Rokietnica gas field, discovered by the Polish Oil and Gas Company, where the closest Rokietnica- 2 well is located approximately $2550 \mathrm{~m}$ from the seismic profile. The width of the gas-bearing zone along the course of the section was estimated at $2 \mathrm{~km}$. It results from the lithologic and reservoir data analysis and synthetic seismogram for the Rokietnica-2 well that the top of the porous, gas-saturated reservoir is related to the Ps2 negative reflection that pinches out beneath the base of the Zechstein rocks in the place of the orthogonal projection of the Rokietnica-2 well. It is worth noting that the seismic record is good enough to enable the interpretation of subtle dislocations of reservoir layers (the red dashed line) beneath the base of the Zechstein rocks (Fig. 4), within the Rotliegend deposits.

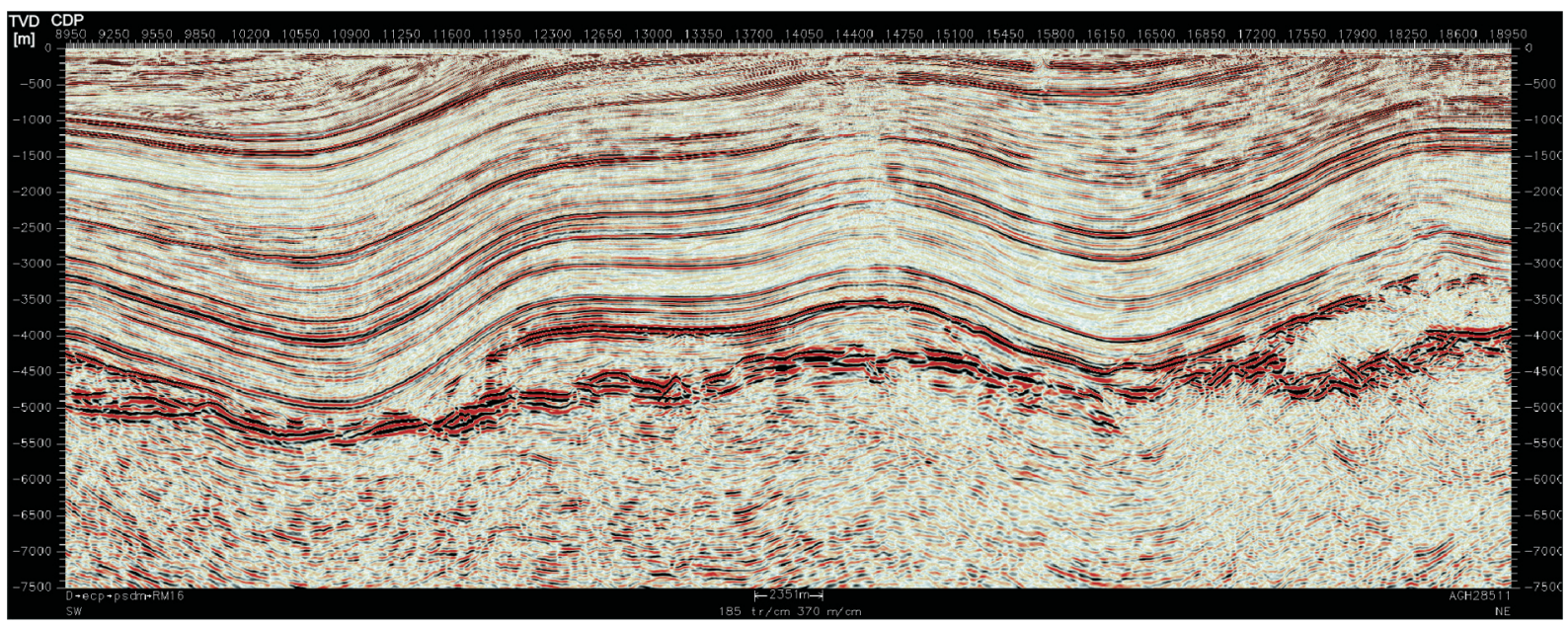

Fig. 3. The image of the Chodziez structure in the seismic record, the central fragment of the Obrzycko-Zabartowo (AGH2) profile

In the area of the Pomeranian Swell, in the AGH2 Obrzycko-Zabartowo profile, it is worth noting the strong reflections beneath the base of the Zechstein rocks, approx. $12-15 \mathrm{~km}$ to the south of the Zabartowo-1 well. Two pairs of quasiparallel, discontinuous reflections (max.-min.), stretching approx. $3 \mathrm{~km}$ and inclined northward at an angle of about $20-15^{\circ}$, are pinching out to the south beneath the $\mathrm{Z1}$ ' boundary (top of the
Rotliegend). The dip angle of the reflections is decreasing with depth to $0^{\circ}$ (approx. 150-200 ms, 350-400 $\mathrm{m}$ beneath the $\mathrm{Z1}$ ' boundary). From the south, these reflections are additionally cut off by the normal fault with a vertical slip of approx. $100 \mathrm{~m}$. The seismic record below suggests the presence of an elevation of the basement; the above-described reflection package pinches out at its northern slope. It cannot be ruled out that 
these are aeolian or fluvial sandstones of the Rotliegend.

From the point of view of searching for hydrocarbon traps, the most interesting seismic record in the basement of the Zechstein rocks occurs in the Zabartowo area. Both the base of the Zechstein rocks (the Z1' boundary) and the base of the Rotliegend/top of the Carboniferous deposits (the C boundary) are relatively well imaged. Their correlation does not raise any doubts in terms of the consideration of the stratigraphic tie to the Zabartowo-1 and Zabartowo-2 wells. It results from the well data and seismic record that the Rotliegend deposits are pinching out to the north $(692 \mathrm{~m}$ in Z-1 and 396.5 in Z-2). In the Zabartowo-1 well, the lithologic section of these deposits in their topmost and central parts is poorly diversified, showing claystones and siltstones of the playa with individual thin sandstone layers. It is reflected in the seismic record in which (as it is shown by the synthetic seismogram for the Zabartowo-1 well), besides the probable multiple reflections in the topmost part of the section, no real reflections can be observed. Only at the base of the section does a relatively strong negative reflection with two positive lateral extrema appear, which correlates with the aeolian and fluvial sandstone horizon in the interval from $4217 \mathrm{~m}(-4107 \mathrm{~m})$ down to $4262 \mathrm{~m}(-4152 \mathrm{~m})$. The research profile enabled the imaging of this horizon for the first time. We can observe that it pinches out approx. $600 \mathrm{~m}$ to the north of the Zabartowo-1 well.

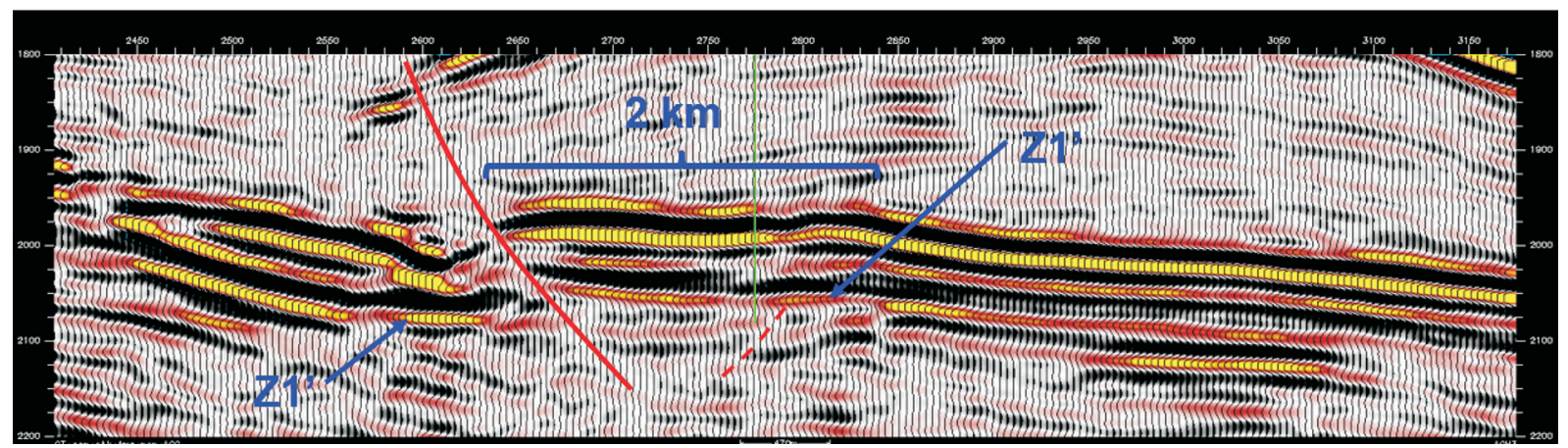

Fig. 4. The tectonically sealed structural trap in the seismic section of the AGH3 Golęczewo-Szubin profile (prestack time migration). Z1' - the base of the Zechstein/top of the Rotliegend (Zajac 2015)

\section{LITHOLOGIC TRAPS}

This results from the analysis of the AGH2 Obrzycko-Zabartowo research profile and archival profiles that the pinching out of the aeolian sandstone horizon between the Zabartowo-1 and Zabartowo-2 wells may represent an example of a lithologic trap. Of course, an appropriate spatial configuration of the border of the sandstone horizon extent is a condition of the existence of such a trap. On the basis of the constructed geologicseismic model it can be inferred that in these areas there is a good chance of discovering lithologic traps ("embayment reservoirs") in the horizon of the "Zabartowo Sandstones", especially in light of the fact that the AGH2 profile proved that seismic mapping of such traps is possible.

Exploration prospects should also be related to the system of normal faults forming the northern margin of the graben in the Rotliegend deposits, located to the south of the Zabartowo-1 well. As it can be observed in the seismic record, the aeolian sandstone horizon found in this well is thrown southward (downdip) by the system of these faults in such a way that it is sealed from the north by impermeable claystones of the lower playa of the upthrown side.

\section{COMBINATION LITHOLOGIC AND STRUCTURAL TRAPS}

To the south, the downdip, the Zabartowo aeolian sandstone horizon is thrown by normal step faults. When the vertical slip is bigger than the thickness of the sandstone layer, the sandstones are sealed from the north by impermeable playa claystones. A combination of an appropriate spatial configuration of the extent of these sandstones (as it was in case of the earlier discussed lithologic trap) 
with such a sealing may form a reservoir trap of the lithologic and structural type. The occurrence of the lithologic and structural trap at the top of the Rotliegend deposits is also suggested by the seismic record in the zone located approx. $13 \mathrm{~km}$ to the south of the Zabartowo-1 well. It cannot be excluded that the strong seismic reflections inclined to the north and pinching out beneath the sub-Zechstein surface come from layers of aeolian sandstones or porous fluvial sandstones.

\section{CONCLUSIONS}

The innovative methodological concepts applied to seismic measurements and data processing can be confirmed by the comparative analysis for the Szamotuły-Golęczewo tectonic zone, where the results of the seismic image from the 3D survey (Fig. 5), carried out by the Polish petroleum industry were compared with results of the $2 \mathrm{D}$ profile (AGH3 - Fig. 6), completed by the AGH University of Science and Technology in the framework of the project. In spite of the fact that the 3D seismic record should theoretically be significantly better than the $2 \mathrm{D}$ record, the seismic imaging of the tectonic structure on the $2 \mathrm{D}$ seismic section is more detailed than on the 3D. It directly results from the application of the considerably longer offset in the 2D survey and decidedly better control of the fold than in the 3D survey.

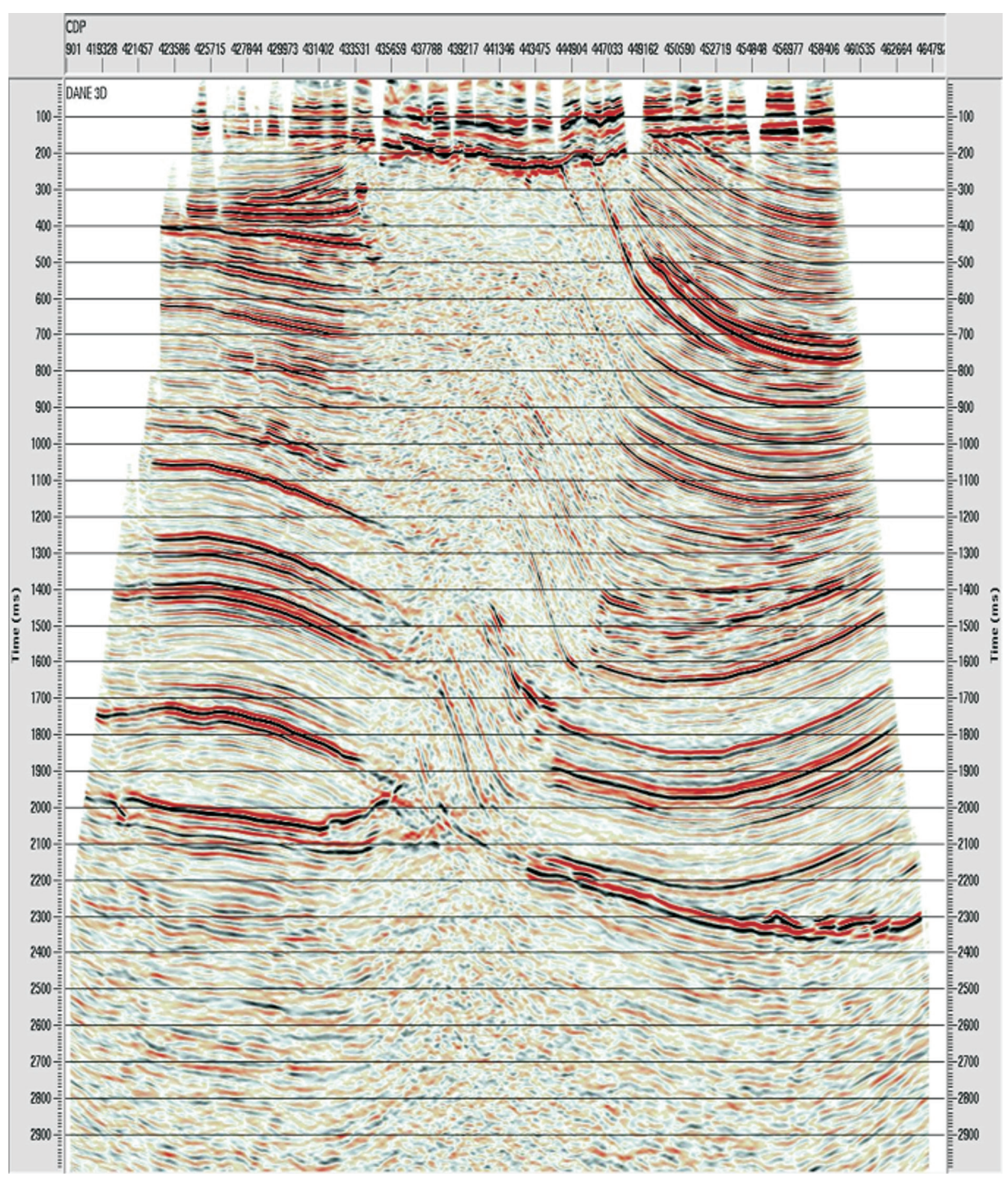

Fig. 5. Seismic section from the $3 D P G N i G$ survey along the trace of the SW fragment of the AGH3 profile (Arch. PGNiG SA) 


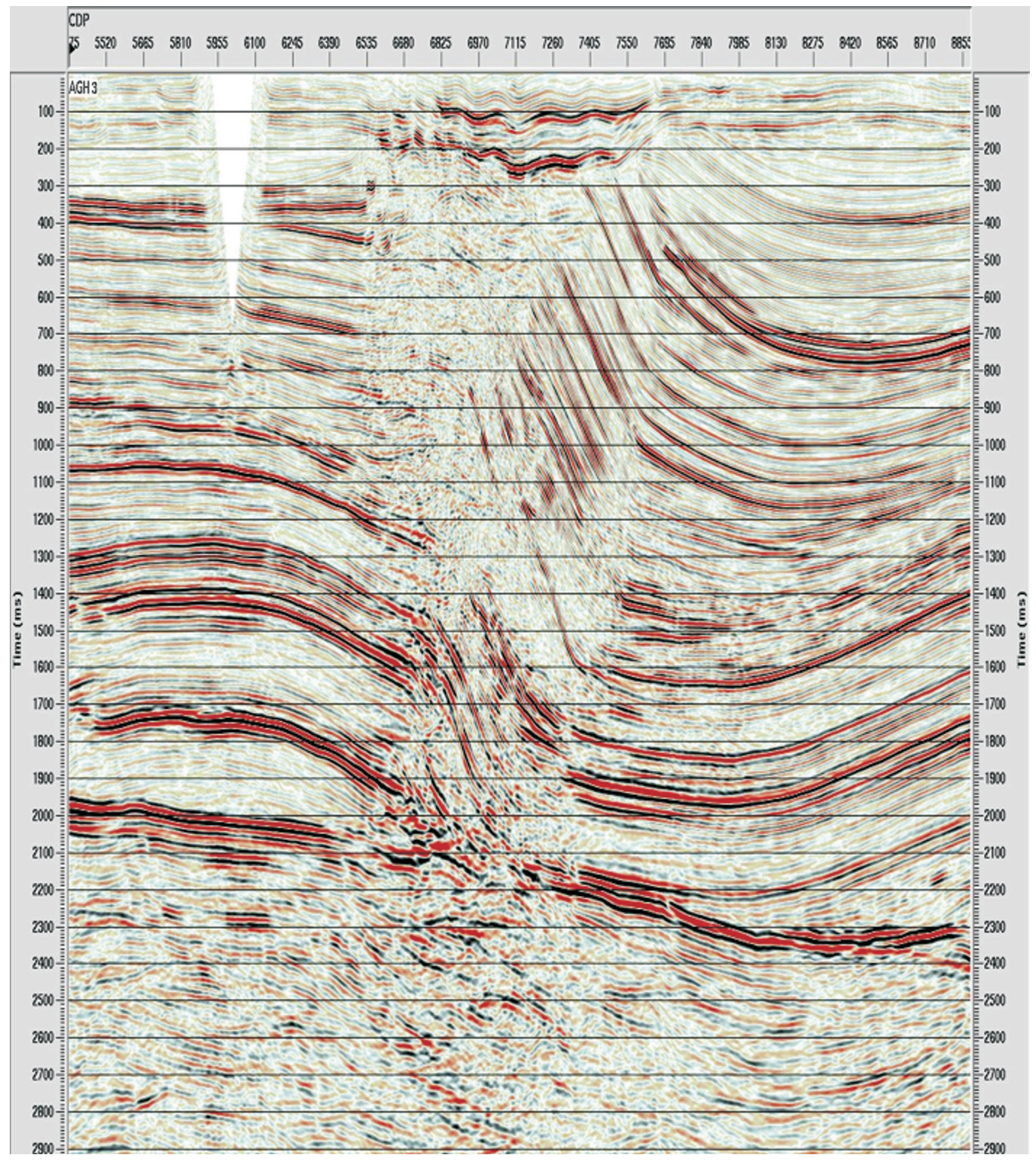

Fig. 6. Seismic $2 D$ AGH section - the SW fragment of the AGH3 profile

The completion of the experimental seismic profiles (AGH1, AGH2, AGH3 and AGH4) by the AGH University of Science and Technology enabled the identification of reservoir sandstone layers and their pinchouts within the clayey-silty deposits of the playa type for the first time in Rotliegend formation studies. The seismic record also allows for the interpretation of subtle dislocations beneath the base of the Zechstein rocks. It results from the characteristic seismic profile AGH2 (Zabartowo-1 - Zabartowo-2) that there is a possibility of discovering lithologic traps in the horizon of the "Zabartowo Sandstones". The characterization of the seismic section opens up new opportunities for prospecting for gas fields in the Rotliegend formation, with resources of the order of more than ten to several tens of million cubic meters and, in some zones of the deep basin, the possibility of discovering much larger gas fields.

The presented publication was prepared during work conducted within the framework of the Operational Programme Innovative Economy 2007-2013, Priority I: Research and Development of Modern Technologies, Sub-measure 1.1.2 Strategic programmes of scientific research and development works. The title of the project was "Improvement of the effectiveness of seismic survey in 
prospecting and exploration of gas fields in the Rotliegend formation". The project was co-financed by the European Union from the European Regional Development Fund. The AGH-UST Contract No. 72.72.10.8425/C72 was carried out from 30 December 2009 to 31 December 2015. During the realization of the project, the beneficiary of which was AGH University of Science and Technology, Krakow, Poland, Faculty of Geology, Geophysics and Environmental Protection, Department of Fossil Fuels, under the management of Prof. Wojciech Górecki and Dr. Tomasz Maćkowski, the following institutions co-operated: the Oil and Gas Institute in Kraków, Warsaw University, the Polish Oil and Gas Company (PGNiG SA), FX Energy, PBG Geophysical Exploration Co. Ltd, Geofizyka Toruń, the Maritime University of Szczecin, the Warsaw University of Technology, Nature Conservation Bureau, TETRALE Technologies Group, Calgary, Canada, and others.

\section{REFERENCES}

Bailey R.J. \& Lloyd D.A., 2001. A log correlation of the Rotliegend of the northern Cleaver Bank High; the search for controls on reservoir sand distribution. Petroleum Geoscience, 7, 351-358.

Burzewski W., Górecki W., Maćkowski T., Papiernik B. \& Reicher B., 2009. Zasoby prognostyczne - nieodkryty potencjał gazu ziemnego w polskim basenie czerwonego spągowca. Geologia: Kwartalnik Akademii Górniczo-Hutniczej im. Stanisława Staszica w Krakowie, 35, 2/1, 123-128.

Cornford C., 1998. Source rocks and hydrocarbons of the North Sea. [in]: Glennie K.W. (ed.), Petroleum geology of the North Sea-Basic concepts and recent advances, Blackwell Scientific Publisher, London. DOI 10.1002/9781444313413.ch11.
Dadlez R., Marek S. \& Pokorski J. (red.), 2000. Mapa geologiczna Polski bez utworów kenozoiku. Wydawnictwo Kartograficzne PAE, Warszawa.

Gautier D.L., 2003. Carboniferous-Rotliegend Total Petroleum System Description and Assessment Results Summary. U. S. Geological Survey Bulletin, 2211, 1-24.

Glennie K.W. (ed.), 1990. Petroleum geology of the North SeaBasic concepts and recent advances. Blackwell Scientific Publisher, London.

Górecki W. (red.), 2008. Zasoby prognostyczne, nieodkryty potencjat gazu ziemnego w utworach czerwonego spagowca $i$ wapienia cechsztyńskiego $w$ Polsce [Prognostic Resources and Undiscovered Natural Gas Potential of Rotliegend and Zechstein Limestone Deposits in Poland]. Unpublished report of the project no. 562/ 2005/Wn-06/ FG-sm-tx/D funded by Ministry of Environment of Poland in 2005-2008, Arch. Department of Fossil Fuels, Faculty of Geology, Geophysics and Environmental Protection, AGH UST, Krakow, Poland.

Górecki W. \& Maćkowski T. (red.), 2015. Poprawa efektywności badań sejsmicznych w poszukiwaniach i rozpoznawaniu złóż gazu ziemnego w utworach formacji czerwonego spagowca [Improvement of the effectiveness of seismic survey in prospecting, exploration and appraisal of gas fields in the Rotliegend formations]. Report of the project 2009-2015 no. 72.72.10.8425/C72, Arch. Dept. of Fossil Fuels, Faculty of Geology, Geophysics and Environmental Protection, AGH University of Science and Technology, Krakow, Poland.

Papiernik B., Górecki W. \& Pasternacki A., 2010. Wstępne wyniki modelowań przestrzennych (3D) parametrów petrofizycznych skał podczas poszukiwań stref występowania gazu zamkniętego w polskim basenie czerwonego spągowca. Przegląd Geologiczny, 58, 4, 352-364.

Zając A., 2015. [in:] Górecki W. \& Maćkowski T. (red.), Poprawa efektywności badań sejsmicznych $w$ poszukiwaniach i rozpoznawaniu złóż gazu ziemnego w utworach formacji czerwonego spagowca, Report of the project 2009-2015 no. 72.72.10.8425/C72, Arch. Dept. of Fossil Fuels, Faculty of Geology, Geophysics and Environmental Protection, AGH University of Science and Technology, Krakow, Poland.

Ziegler P.A., 1990. Geological Atlas of Western and Central Europe. Shell Internationale Petroleum Maatschappij B.V., Amsterdam. 